\title{
Nietzsche: Crítica à Linguagem como Crítica à Moral
}

\author{
Thelma Lessa da Fonseca*
}

Resumo: Este texto busca mostrar que a crítica à linguagem empreendida por Nietzsche, já em seus primeiros escritos sobre o tema, não pode ser tomada em um sentido meramente epistemológico, uma vez que enfoca a discussão sobre o conhecimento a partir de uma perspectiva moral.

Palavras-chave: impulso à verdade - retórica - moral - linguagem

Os escritos a serem aqui tratados pertencem ao período que se pode denominar, talvez de forma demasiado genérica, "período de juventude"; mais exatamente, trata-se de escritos datados de 1872 e 1873. Partiremos de um pequeno trecho de Ueber Wahrheit und Luege im aussermoralischen Sinne, trecho esse que resume uma pergunta central desse escrito, e, para esclarecê-la, nos remeteremos ao texto conhecido por "Curso de Retórica". A pergunta a que me refiro é a pergunta pela origem do "impulso à verdade", a qual será aqui focalizada como "porta de entrada", por assim dizer, para que se possa adentrar o sentido da crítica ao conhecimento que move o primeiro desses textos.

Uma das questões que a leitura de Wahrheit und Luege impõe ao seu leitor é aquela voltada para esclarecer que noção de verdade teria o autor

* Professora do Departamento de Filosofia da Universidade Estadual Paulista (Marília) e aluna de Pós-Graduação do Departamento de Filosofia da Universidade de São Paulo. 
em mente ao anunciar que o conhecimento não está apto a alcançá-la, ou seja, contra que conceito de verdade se volta sua crítica.

$\mathrm{O}$ texto parece não deixar dúvidas quanto à existência de uma recusa da idéia de verdade como adequação no sentido clássico, tal como é possível entrever no trecho que se segue:

"Acreditamos saber algo das coisas mesmas, se falamos de árvores, cores, neve e flores, e no entanto não possuímos nada mais do que metáforas das coisas, que de modo nenhum correspondem às entidades de origem. (...) Em todo caso, portanto, não é logicamente que ocorre a gênese da linguagem, e o material inteiro, no qual e com o qual mais tarde o homem da verdade, o pesquisador, o filósofo, trabalha e constrói, provém, se não da Cucolândia das Nuvens, em todo caso não da essência das coisas" (Nietzsche 11, p. 879; grifos meus)(1).

Vê-se que Nietzsche refere-se aí à ilusão do filósofo ou do pesquisador de que à linguagem sobre a qual edifica seu constructo teórico corresponda algo das coisas em si mesmas. Tal ilusão é combatida pelo autor na medida em que este entende que a linguagem em geral nada contém da essência das coisas, já que é constituída de metáforas.

Assumamos, provisoriamente, a hipótese de que a crítica de Nietzsche ao conhecimento, erigida sobre uma concepção específica da linguagem - a saber, da palavra como originalmente metafórica -, tenha como alvo a noção de verdade como adaequatio. A seguir, leiamos o trecho seguinte sob o prisma desta hipótese:

"Continuamos ainda sem saber de onde provém o impulso à verdade: pois até agora só ouvimos falar da obrigação que a sociedade, para existir, estabelece: de dizer a verdade, isto é, de usar as metáforas usuais, portanto, expresso moralmente: da obrigação de mentir segundo uma convenção sólida, mentir em rebanho, em um estilo obrigatório para todos" (id., ibid., p. 878; grifos meus). 
Vê-se que o autor contrapõe ao Trieb zur Wahrheit o respeito às convenções da linguagem, o que ele denomina "dizer a verdade". Pode-se facilmente compreender em que medida as convenções da linguagem são necessárias na vida em coletividade, é o que o texto parece nos dizer; o enigma proposto está, portanto, em explicar de que maneira surge um impulso espontâneo em direção à verdade que teria impelido os homens a atribuírem à linguagem uma função que excede esta. Dois pontos marcam a diferença entre "impulso à verdade" e "obrigação de seguir as convenções": de um lado, quando se fala em "impulso", está se referindo a um ímpeto, a um movimento de origem interna ao indivíduo em direção a algo; além disso, este impulso quer a verdade, o que estamos aqui provisoriamente supondo ser um reflexo da essência das coisas. De outro lado, "obrigação de mentir segundo convenções" remete à idéia de uma coerção imposta pelo todo social ao indivíduo, convenções estas que não se pretendem legitimadas por um referencial externo às próprias relações humanas, mas que visam apenas o respeito às regras estabelecidas entre homem e homem. Aqui, se estaria buscando a mera veracidade. Com isso, pode-se compreender que Nietzsche supõe que tal impulso está voltado para algo outro do que o respeito às convenções lingüísticas, para algo distinto de uma "mentira" coletiva. Assim, é possível entender que a crítica de Nietzsche nesse texto tem como alvo a pretensão de que a linguagem seja capaz de refletir as coisas tal como são em si mesmas e, para delatar a ausência de fundamentos desta pretensão, ele estaria enfatizando o caráter puramente convencional da linguagem.

Este trecho não é o único que nos leva a interpretar a crítica de Nietzsche à linguagem e ao conhecimento como uma crítica voltada para destruir os fundamentos da idéia de verdade como adequação no sentido clássico, em oposição a uma idéia (supostamente aceita por ele) de verdade como acordo deliberado entre os membros da coletividade. Em se atentando para este texto, nota-se que esta não é a única vez que a palavra "convenção" (Convention) aparece como contraponto da crença na existência de uma relação originária entre palavra e "coisa". Isso nos leva à convicção de que o autor se apóia no caráter convencional da linguagem para promover uma recusa da crença de que a palavra é uma decorrência de seu conteúdo conceitual. Lido desta forma, tudo se passa nesse texto como se a "novidade" 
pretendida pela crítica nietzschiana à linguagem e, conseqüentemente, ao conhecimento, seria a de anunciar que não há efetivo conhecer porque não há, na linguagem, correspondência entre palavra e "coisa". Suposta, aí, seria a idéia de que a simples convenção não poderia fundar conhecimento algum, o que resultaria em afirmar que não havendo adequação - havendo apenas convenção - não há conhecimento.

Se assim for, a crítica de Nietzsche ao conhecimento seria facilmente colocada de lado por uma idéia de conhecimento que não estivesse estruturada sobre o conceito de adaequatio. A pergunta que se impõe a partir de então é: teria passado despercebida pelo autor a possibilidade de fundar o conhecimento sobre outras bases? Teria ele julgado que a recusa da idéia de adequação no sentido clássico é suficiente para questionar o alcance do conhecimento em geral?

Parece-me que, ao se buscar compreender exatamente qual o sentido desta "obrigação de usar as metáforas usuais", pode-se observar que a idéia de convenção na linguagem não constitui, aos olhos do autor, uma real alternativa para a idéia de uma conformidade entre palavra e "coisa". Se isso puder ser comprovado, será possível constatar que a crítica de Nietzsche ao conhecimento não se reduz a uma crítica à idéia de adaequatio.

As anotações de 1872, ${ }^{(2)}$ conhecidas pelo título de "Curso de Retórica"(3), contêm diversos desenvolvimentos da discussão sobre a linguagem que nos fornecem subsídios para compreender discussões apresentadas de forma demasiado sucinta em Wahrheit und Luege. Entre estas, há a defesa do caráter originalmente metafórico da linguagem, caráter esse que aparentemente surge como contraponto da idéia de uma linguagem adequada às "coisas", ou seja, como contraponto da crença na existência de uma relação biunívoca entre palavra e "coisa". Assim sendo, irei me remeter a este texto (Rhetorik) com o intuito de buscar indicações de que a crítica nietzschiana à linguagem recai também sobre a idéia de verdade como convenção, o que implicaria, portanto, uma ampliação do âmbito da crítica ao conhecimento, uma vez que esta não se limitaria à idéia de verdade como adequação ${ }^{(4)}$.

Aparentemente, o propósito desse texto é o de promover uma reabilitação da retórica. Entretanto, mais do que isso, será alcançado aí o questionamento mesmo da possibilidade de uma linguagem não retórica. Este 
questionamento parte da definição aristotélica de retórica(5): "Admitamos pois que a retórica é a força ${ }^{(6)}$ de considerar teoricamente o que, em cada caso, é o mais conveniente para persuadir" (Aristóteles 3, p. 76).

A partir desse trecho, Nietzsche analisa a definição aristotélica termo a termo, análise esta que podemos resumir em três pontos ${ }^{(7)}$, quais sejam:

1. "Persuadir segundo o conveniente": Nietzsche entende por isso que se trata de um discurso que visa a opinião do ouvinte, mesmo em se tratando de uma causa duvidosa, isto é, mesmo quando se incute uma opinião errônea ou falsa.

A retórica, tornada arte dessa maneira, aparenta-se à dialética, diz Aristóteles, pois tanto uma como outra visam a opinião (doxa) do ouvinte ou leitor. Ambas podem ser usadas para diferenciar o verdadeiro do aparente e, neste caso, auxiliarem a instrução ${ }^{(8)}$, mas unicamente o fazem se atendo à opinião. Quanto a esse assunto Nietzsche menciona o trecho do Organon no qual consta: "Em filosofia é preciso tratar dessas coisas segundo a verdade, mas na dialética é suficiente se ater à opinião (doxa)" (id., ibid., p. 33). Assim, a retórica não consiste, por si mesma, em instrumento capaz de levar ao conhecimento (epistemé).

2. "Em cada caso" significa que ela é puramente formal, isto é, é aplicável a diversas disciplinas. Sua peculiaridade está em que ela "(...) não pertence a um gênero definido" (id., ibid., p. 75) como as demais artes, as quais são "(...)cada uma para seu objeto, próprias ao ensinamento e à persuasão (id., ibid., p. 76). Assim, ela consiste em algo que, como meio, pode servir a diversas finalidades.

3. "Considerar teoricamente" (theorisái): este termo indica, pensa Nietzsche, que a retórica supõe um estudo, uma preparação teórica ${ }^{(9)}$. Ela não consiste numa habilidade que se desenvolve espontaneamente, mas, antes, representa algo alcançado por um esforço especulativo, por um trabalho teórico. Há um trecho anterior ao citado no texto de Aristóteles que corrobora essa interpretação de Nietzsche, qual seja: “(...) A retórica não tem a função de persuadir, mas de ver os meios de persuadir que comporta cada assunto" (id., ibid., p. 74) $)^{(10)}$.

Assim, os três pontos permitem a Nietzsche concluir que a retórica, para Aristóteles, conforma-se como um instrumento a serviço de uma inten- 
ção determinada, de um fim previamente estabelecido. Ele observa que, para os autores antigos de uma maneira geral, a arte (tekhné) retórica consiste no estudo e no conhecimento da persuasão(11). Em Platão, continua o autor, a retórica é definida como um artifício que, embora "(...)situado no mesmo nível da arte culinária" (Nietzsche 10, p. 289), exige o conhecimento de uma técnica. Assim, a arte da oratória exige uma preparação, um domínio do verossímil que permita suscitar determinadas paixões nos ouvintes. Enquanto artifício, ela não é um dom natural, não se desenvolve espontaneamente, mas unicamente em vista de uma reação específica a ser provocada no interlocutor. É, portanto, movida por uma intenção. Desta forma, a partir da definição de Aristóteles, Nietzsche ressalta a importância do termo "theoresái" na definição de retórica, entendendo que, para o autor antigo, ela é resultado de um esforço especulativo, de uma "consideração teórica" (id., ibid., p. 292) movida por uma intenção determinada.

Diante disso, conclui Nietzsche: "Os antigos só podiam conceber a arte como consciente (...)" (id., ibid., p. 315). Quando as figuras de linguagem eram usadas de outra forma, esse uso era entendido como fruto da ignorância no domínio da língua ${ }^{(12)}$. Neste caso, tais figuras seriam denotadoras de um uso impróprio da palavra. Com isso, encerramos a primeira parte do nosso trajeto, a qual buscou resumir alguns elementos da compreensão que Nietzsche tem, no texto tratado, do conceito antigo de "retórica". Cabe, agora, abordar de que maneira esta compreensão fornece material para sua própria concepção de linguagem como fundamentalmente retórica.

Ainda em Rhetorik, a partir da definição aristotélica, o autor irá entender que não há linguagem que não seja retórica. Contudo, essa definição é tomada com uma ressalva: não há necessariamente trabalho consciente na criação das figuras de linguagem, isto é, nem todo uso da retórica é movido por intenções determinadas. A retórica, para Aristóteles, designa, entende Nietzsche, um "(...) uso consciente dos artifícios (Kunstmittel) do discurso" (id., ibid., p. 297) quando abordada como uma arte. Entretanto, diz ele, “(...) não é difícil de provar que isto a que chamamos 'retórica' para designar os meios de uma arte consciente já estava em ação, como os meios de uma arte inconsciente (unbewusst), na linguagem e na formação desta $\mathrm{e}$ 
mesmo (não é difícil de provar) que a retórica é um aperfeiçoamento dos artifícios já presentes na linguagem" (Nietzsche 10, pp. 297-298) ${ }^{(13)}$. Para Nietzsche, aquilo que os antigos consideravam fruto de um trabalho movido por esforço especulativo, esforço este que supunha uma intenção determinada conscientemente, não é determinante da criação da metáfora (no que diz respeito à palavra) e, tampouco, da retórica (no que diz respeito à linguagem em geral). Ao contrário, pensa Nietzsche, "artifício" pode ser produto de um trabalho inconsciente.

O primeiro dos pontos em que se apóia a idéia de que a retórica não consiste num uso específico da linguagem, mas constitui sua própria essência, pode ser exposto tal como se segue: dada a definição aristotélica de retórica anteriormente citada, qual seja, "a retórica é a força de considerar teoricamente o mais indicado para persuadir em cada caso" (Aristóteles 3, p. 76), Nietzsche afirma que toda palavra é um tropo. A palavra apenas assinala uma característica que se apresenta como relevante e, para isso, recorre-se a uma imagem que enfatiza esta característica. Há três figuras de linguagem que o autor menciona para mostrar que, na sua origem, cada palavra é fixada segundo parâmetros puramente subjetivos: sinédoque ${ }^{(14)}$, metáfora e metonímia.

Por "sinédoque" Nietzsche entende o recurso retórico de tomar a parte pelo todo. Ele crê que diversas denominações são criadas por meio dessa figura, como, por exemplo, a palavra "serpente": "(...) serpens designando a serpente como algo que se arrasta; mas por que serpens não significa também caracol?" (Nietzsche 10, p. 299). Aqui se tem o caso em que uma característica, comum a outros animais, é escolhida para determinar um animal. Entretanto, em outras línguas, o mesmo animal é designado por denominações oriundas de outras características: no grego, drákon significa "aquele que tem o olhar brilhante" (id., ibid.); no latim, anguis quer dizer "constrictor" (id., ibid.). Através deste exemplo, pode-se ver a arbitrariedade com que características parciais pretendem reproduzir um todo.

A segunda figura, a metáfora, é entendida por Nietzsche como o procedimento de transpor significações (umdeuten) já existentes. Através desse tropo não se criam, portanto, palavras, mas elas apenas são transpostas de um significado para outro. Isso ocorre quando se diz "pé", "flanco", "veia", 
ou "cabeça" ao se referir a partes de uma montanha (Nietzsche 10, pp. 299. 300 ; obs.: seguem-se outros exemplos) $)^{(15)}$.

Como terceiro tropo, há a metonímia. Esta é entendida pelo autor como a substituição da causa pelo efeito. Do mesmo modo que o retórico diz "suor" em lugar de "trabalho" (id., ibid.), dizemos: "(...) 'a bebida é amarga', em vez de dizermos 'provoca em nós tal sensação"”. Outro exemplo se encontra no parentesco entre leússo, lux e luceo (id., ibid.), onde a palavra "enxergar" é extraída do termo próprio para designar "luz" ou "brilho" (id., ibid.).(16)

A partir desses três exemplos de figuras constituintes da língua estabelecida, Nietzsche crê poder concluir que os tropos não são exceções e, tampouco, distorções de palavras já existentes, mas caracterizam a própria natureza da palavra. Diante disso, "da mesma forma que há tão pouca diferença entre as próprias palavras e os tropos, há a mesma diferença-mínima - entre o discurso autêntico e as chamadas figuras retóricas" (id., ibid.). A argumentação do autor se desenvolve, como se pode notar, no sentido de questionar a existência mesma de um uso "próprio" da linguagem, uso esse que determinaria a autenticidade do discurso. No que tange à sua gênese, a linguagem é retórica, pois o tropo está na origem da palavra. Mas, para que possa ser concretizada a generalização daqueles três exemplos para a linguagem enquanto tal, ainda restará a Nietzsche mostrar que também do ponto de vista de seus fins a linguagem apenas visa a persuasão ${ }^{(17)}$.

Abordemos, portanto, o segundo argumento nietzschiano em favor da idéia de que a linguagem em geral não se distingue substancialmente da retórica. Este segundo argumento decorre do primeiro e o completa, na medida em que permite sua generalização.

Sendo a palavra uma figura de linguagem, "não são as coisas que penetram na consciência, mas nossa maneira de nos relacionarmos com elas, o pithanón" (id., ibid.). Dois obstáculos se apresentam caso se queira defender a existência da exatidão na linguagem: em primeiro lugar, há o fato de que o homem não apreende "fatos", mas apenas excitações nervosas (conforme foi visto anteriormente, o nome é marcado pela pura arbitrariedade). Há uma diferença de natureza entre estas excitações experimentadas subjetivamente e sua suposta "causa"; apenas ocorre que essa excitação nervosa é projetada no exterior através de uma imagem sonora e a atribuímos, por 
essa razão, a uma causa externa da qual somente temos notícia através de um outro processo de seqüências nervosas a que denominamos "pensamento"(18).

Através daqueles exemplos, pôde-se ver que diversas denominações são arbitrariamente fixadas, ou seja, que é possível encontrar, na origem das denominações mais simples, procedimentos chamados "retóricos". Dado isso, a questão que aqui nos importa (enquanto segundo argumento em favor do caráter retórico da linguagem em geral) reside no fato de que a arbitrariedade que marca o processo de criação das palavras indica que não está ao alcance do ouvinte uma "reconstrução" do estímulo originário de uma sensação interna do orador. Da mesma forma que não existem passagens necessárias entre meu estímulo e a imagem sonora que encontro para designá-lo, não há necessidade alguma na transposição que meu ouvinte tenta operar entre tal imagem e sua sensação interna, mesmo que ele apenas tenha como fim o de se representar o que eu vivencio internamente ${ }^{(19)}$.

Assim sendo, caso se queira defender a idéia de que a linguagem serve para comunicar estados internos, resta esclarecer “(...) como uma imagem sonora poderia traduzir um estado d'alma” (Nietzsche 10, p. 299). Para que a linguagem pudesse reconstituí-lo, seria necessário que ela fosse formada do mesmo material que aquele constituinte da sensação interna. Dado que isso não ocorre, toda linguagem somente pode comunicar uma doxa e não uma epistemé.

Portanto, também se considerarmos a palavra como meio de transmitir impressões subjetivas, a linguagem não visa a instrução, mas apenas a persuasão (peíthein), se por "persuasão" entendermos que a comunicação através da linguagem somente objetiva suscitar emoções. Dado que a palavra é incapaz de espelhar um estado d'alma, apenas poderíamos "comunicar emoções internas" se supusermos que a "paixão" suscitada no ouvinte é a mesma que experimentamos no momento. Pretender se comunicar desta forma é entender a linguagem como meio de persuasão ${ }^{(20)}$, pois significa pretender despertar determinada paixão em meu interlocutor, pretensão essa que de nenhum modo serviria de prova em favor da precisão da linguagem. Ao contrário, ela apenas aproximaria a linguagem em geral da retórica ${ }^{(21)}$. Estas duas idéias - toda palavra é um tropo e toda linguagem apenas visa a persuasão- levam Nietzsche a entender que o engano dos autores antigos, engano esse que 
resultou na repulsa da retórica como uso ilegítimo da língua, é resultante da crença de que "artifício" (Kunstmittel) no que diz respeito à linguagem é apenas alcançado por um trabalho teórico, resultado de um esforço intencional, isto é, resultante da crença de que "artifício" designa um trabalho consciente. A este uso "artificial" se oporia, para os gregos, um uso "natural", isto é, um uso que se apropriasse da linguagem tal como ela naturalmente se apresenta, uso esse que preservaria a relação originária das palavras com seus significados sem a interferência da ação humana. No entanto, o artifício (criação artística e arbitrária) provém, pensa Nietzsche, de uma atividade anterior à própria criação da consciência. Com isso, não é apenas "intencionalmente" que criamos termos, que forjamos palavras. Neste sentido, toda linguagem pode ser entendida como "artificial".

Até aqui é empreendida a recusa da idéia de uma linguagem natural. Não há, portanto, diferença qualitativa entre discurso "puro" - que fosse um uso adequado à origem da linguagem - e um uso retórico, consistindo este numa corrupção dos sentidos originais. Não há, tampouco, distinção tácita entre um uso que, respeitando tal origem, visasse a instrução, o conhecimento (epistemé), e outro que apenas buscasse a persuasão, isto é, voltado para suscitar determinadas paixões no ouvinte (doxa). A questão que se coloca é de que maneira, então, se teria criado a idéia de "pureza" da língua? Aqui começa a ser construída a pergunta - explicitamente formulada em Ueber Wahrheit und Luege - pela origem do impulso à verdade: se não há uma linguagem engendrada a partir de determinações externas, isto é, engendrada a partir das próprias "coisas" que as palavras buscam designar, então, como se instaurou no homem aquela expectativa de que o discurso do conhecimento pudesse refletir algo do "em si"?

Com isso, chegamos ao terceiro ponto desta breve exposição. Tendo visto como Nietzsche entende a compreensão da retórica pelos antigos, tendo detectado os pontos desta concepção de que ele parte para afirmar que toda linguagem é retórica, poderemos agora verificar qual o problema específico que o autor levanta diante dessas considerações. Este problema está indicado na pergunta pela origem da crença em um uso próprio da linguagem, uso este que seria fiel à exatidão da palavra. Para Nietzsche resta, enfim, perguntar como teria surgido a idéia de que há um uso próprio da 
linguagem e outro impróprio, este último podendo ser "legítimo", quando elevado à categoria de "arte", ou desprezível, se resultado de uma prática impensada.

O problema assumido pelo autor a partir de então é o problema expresso na pergunta pela origem da expectativa de que a linguagem e, consequientemente, o conhecimento em geral possam refletir algo das coisas como são em si mesmas. Este problema é visto como tal, por Nietzsche, a partir do momento em que este entende que a linguagem não possui tamanho alcance. É como se fosse dito: dado esse limite, isto é, dado que a origem da linguagem é marcada pela pura arbitrariedade, o que leva os homens a esperar que ela possa ser outra coisa, isto é, o que alimenta a expectativa de que a linguagem deva representar algo das coisas em si mesmas?

Ao recordarmos nosso objetivo inicial (a saber, o de buscar no "Curso de Retórica" elementos que possam contribuir para o esclarecimento da pergunta nietzschiana pela origem do "impulso à verdade"), cabe agora dedicar atenção à pergunta formulada naquele escrito pela gênese da crença em um discurso "puro". Isso porque a esse discurso é atribuída a tarefa de constituir-se como meio para o alcance de "verdades", como instrumento para o conhecimento.

O trecho de Rhetorik, reproduzido a seguir, aborda justamente a origem da idéia de "pureza":

"Não há, por si mesmo, discurso puro nem impuro. Muito difícil problema (de saber) como se forma o sentimento de pureza e (o problema de saber) como uma sociedade culta (gebildete Gesellschaft) escolhe até circunscrever(22) a totalidade de seu domínio. Evidentemente, neste caso se procede segundo leis e analogias inconscientes (unbewussten); alcança-se uma unidade, uma expressão única: do mesmo modo que a uma tribo corresponde suficientemente um dialeto, a uma sociedade corresponde um estilo sancionado como 'puro'. - Nos períodos de desenvolvimento de uma língua (Sprachwachsthums) o "discurso" não é sobre "pureza": (ele o é) apenas em uma língua acabada” (Nietzsche 10, p. 301; grifos meus). 
Abordemos este trecho termo a termo para que possamos compreender o sentido da pergunta nietzschiana enquanto preocupação voltada para esclarecer a origem deste "sentimento de pureza", com a expectativa de que essa compreensão nos possa ajudar a compreender o sentido da pergunta pelo "Trieb zur Wahrheit".

Em primeiro lugar, "pureza" é reconhecida através de um sentimento (Gefuehl), o que indica que ela não é definida por uma apreensão racional. Enquanto tal, ela não é propriedade do discurso, mas é resultante de uma avaliação que se faz sobre este ou de uma inclinação diante dele. Assim, diz o próprio texto, tal reconhecimento se orienta por "leis e analogias inconscientes", ou seja, por critérios não estabelecidos por deliberação. Não se trata, portanto, de "convenção", se por isso for entendido acordo comum.

Entretanto, em segundo lugar, vê-se que esse reconhecimento tem lugar no contexto social - "estilo sancionado como 'puro' em uma sociedade" -, sendo, desta forma, dado por uma coletividade. Assim, tais critérios, ainda que inconscientes, são de alguma forma comuns, já que a eleição coletiva alcança uma unidade.

Terceiro ponto: esta unidade representa o assentimento coletivo a um estilo entre outros possíveis. O nome para sinalizar esta sanção do todo coletivo a um estilo específico é "pureza".

Finalmente, chega-se ao ponto principal: apenas se pode construir um discurso sobre a "pureza" quando a língua já está criada, quando já existe uma língua formada. A língua fixada, chamada "pura", não é referência do criador da linguagem, mas da coletividade que conserva uma criação dada previamente a ela. Com este passo, Nietzsche separa, em sua discussão sobre a linguagem, origem - criação individual - e uso - fixação pela coletividade. Esta separação se dá da seguinte forma:

Em Rhetorik a explicação para a origem da linguagem é a seguinte: Nietzsche entende, então, que sua uniformidade se deve ao fato de que a linguagem é fruto da criação de um único indivíduo. Se passa às mãos da coletividade, isso ocorre através de uma coerção: "Estes poucos (criadores da linguagem), quando não conseguem impor suas figuras (retóricas) à maioria, apelam contra ela ao usus e falam de barbarismos"(23) (Nietzsche 10, p. 300). Para que a sua criação individual prevaleça diante de novas possí- 
veis criações, o criador da linguagem faz apelo ao "gosto da maioria" e desqualifica qualquer nova denominação como "barbarismo", como ignorância ou uso indevido da linguagem estabelecida. Sub-repticiamente, o artífice da linguagem determina, antes de mais nada, não apenas o uso específico da língua a ser valorizado, mas sim o critério de avaliação. Tal critério está presente quando se associa o mais antigo ao "legítimo", quando se valoriza o usual em relação ao novo, o que se faz ao atribuir artificialidade ao segundo em contraposição ao primeiro, ao se dizer que o "surpreendente" é farsa, mentira, impureza e imprecisão da linguagem, em oposição ao familiar, que configuraria o uso "adequado", "puro". É desta maneira que se alcança impedir que novas criações tomem o lugar das antigas: "Portanto, o puro se define pelo 'não surpreendente' (Nicht-Auffaellige)" (Nietzsche 10, p. 301).

O trecho citado permite concluir que há uma precedência da retórica em relação à idéia de "uso natural" da linguagem, uma vez que aquilo que se entende por "barbarismo" é, na verdade, apenas um recurso - retórico para que se torne possível impor como norma um determinado uso das palavras. A idéia de "uso natural" da linguagem é um artifício retórico (entendendo-se aqui o termo "retórica" segundo a definição aristotélica). A própria diferenciação natural/artificial está a serviço de fins de persuasão: "(...) a arte do orador consiste em não permitir que apareça o artificial: daí o estilo característico que, sem dúvida, é em qualquer caso produto da arte mais elaborada: assim como o 'natural' do bom ator" (id., ibid., p. 306). O "natural" aparece como invenção da arte retórica, para dissimular, através de uma técnica, o fato de que seu discurso visa apenas persuadir os ouvintes. Ele deve fazer parecer que as emoções despertadas em seus interlocutores são as mesmas ou ao menos similares àquelas que ele próprio sente. Tem que ser capaz de aparentar que crê na causa defendida, que é "honesto", isto é, que usa a linguagem de acordo com as regras fixadas. Como é dito em Wahrheit und Luege, o que se espera alcançar com um uso "legítimo" da linguagem é a veracidade.

Não haveria problema algum no fato de se fundamentar uma concepção de verdade sobre uma idéia de veracidade, desde que esta fundamentação estivesse ao alcance de todos. Se isto ocorresse, tratar-se-ia de um acordo comum, o que seria suficiente para legitimar uma concepção de conheci- 
mento sustentada sobre uma idéia de convenção na linguagem. O que torna tal concepção de conhecimento impossível é o fato de que não há convenção nesta idéia de veracidade, mas apenas coerção.

A partir do trecho acima mencionado, pode-se compreender que "barbarismo" é um dispositivo coercitivo que visa restringir a poucos o privilégio da doação dos sentidos. Daí por que não se trata de convenção no estabelecimento da linguagem. Não há comum acordo pois não há consciência, por parte da grande maioria, do caráter fictício destes significados. Há apenas, por um lado, um impulso artístico, criador dessas figuras retóricas e, por outro lado, uma estratégia voltada para conservá-las. Mas, a partir desta compreensão do que significa um uso "legítimo" da linguagem, não há convenção (strictu sensu, isto é, como acordo deliberado) ainda pelo fato de que o uso comum da linguagem pela coletividade é instaurado através de uma imposição, embora não apareça como tal.

A fixidez da linguagem, que encontra no adjetivo "puro" seu coroamento, não é devida à sua origem, pois o criador da língua tem de fazer com que suas criações sejam preservadas pelo uso corrente para que se fixem, para que adquiram o estatuto de denominações "corretas", adequadas. Assim, essa fixidez apenas pode ser atribuída por uma força constante que a mantenha, força esta presente em seu uso. Ela não mais é fruto exclusivo da ação individual; ela é resultante da linguagem usada para a comunicação no interior de uma organização social ${ }^{(24)}$.

Assim, pode-se verificar que Nietzsche não se limita a uma crítica à idéia de verdade como adequação, crítica esta que deixaria intocada uma concepção convencionalista da linguagem. Isso porque não há, para ele, a possibilidade de compreender que a linguagem fora instaurada por um acordo comum. Há, isto sim, a coerção para que se atribua à linguagem uma determinação externa, coerção esta que, quando se impõe de maneira velada, é vivenciada como "impulso à verdade", como apreço espontâneo pela verdade. Assim, pode-se compreender que Nietzsche, ao perguntar pela origem do impulso à verdade, de fato questiona os fundamentos da idéia de verdade como adequação no sentido clássico. No entanto, se ele o faz, tal questionamento está voltado, antes de mais nada, para o anúncio de que a crença em uma conformidade entre linguagem e as coisas em "si mesmas" 
pode ser, ela própria, enquanto crença, fruto de uma coerção. Mas, entrementes, o autor também evidencia que a idéia de que há convenção na linguagem igualmente pode ser resultado de um procedimento coercitivo, mascarador do processo impositivo que determina o "uso adequado" ou legítimo da palavra.

Ao atribuir a fixação da linguagem ao âmbito da comunicação, a discussão terá que se transportar para o terreno da moral, na medida exata em que o próprio pendor à "verdade" reduz-se, aos olhos do autor, à sublimação de uma regra - moral - que impõe a veracidade: “(...) a veracidade (Wahrhaftigkeit) (e a metáfora) produziu a propensão para a verdade. Assim um fenômeno moral, esteticamente generalizado, dá o impulso intelectual" (Nietzsche 9, $\$ 130)$. O impulso à verdade constitui, assim, a introjeção desta regra e a consequiente elevação da "verdade" a um valor per se (id., ibid., § 133). A esta "verdade" não se opõe o erro, a falsidade. Opõe-se a mentira, é o que Nietzsche busca revelar: "O mentiroso usa as designações válidas para fazer aparecer o não-efetivo como efetivo; (...) se ele o faz de maneira egoísta e de resto prejudicial, a sociedade não confiará mais nele e o excluirá de si" (idem 11, p. 881). O respeito ao uso "legítimo" das palavras - a "verdade" - somente tem sentido na situação estabelecida entre falante e ouvinte com a finalidade de checar a fidelidade do primeiro no que diz respeito à sua adesão às regras estabelecidas.

Esta é a forma escolhida pelo autor, sobretudo em Ueber Wahrheit und Luege, para nos dizer que, quando se discute sobre as possibilidades de se alcançar a "verdade", supõe-se que ela deva ser, por si mesma, desejável, necessária, válida. Tal suposição, ao ser questionada na pergunta pela origem do impulso à verdade, desloca o problema do âmbito estrito da teoria do conhecimento para situá-lo no campo da discussão sobre a moral.

Esse tratamento dispensado pelo autor à linguagem enquanto algo que reflete, sobretudo, as constelações de poder entre os homens, nos permite entender que sua crítica à linguagem a situa no terreno delimitado por uma preocupação moral, já que se configura como parâmetro para a avaliação das relações entre homem e homem, e nada poderia esclarecer quanto à suposta relação entre homem e "mundo". As regras que regem a linguagem são refinamentos de normas criadas para manter uma certa hierarquia nas 
relações entre os homens. Tais regras configuram apenas normas sociais quando apresentadas de maneira explícita, como, por exemplo, quando apresentadas na forma de lei. São regras morais quando a norma social não se apresenta como tal, isto é, quando ela se apresenta como um valor per se, como é o caso do valor da verdade.

Assim, o que Nietzsche teria buscado através dessa discussão sobre a retórica poderia ser entendido como uma denúncia da fixação (através da linguagem) das normas que regem as relações entre os homens, isto é, teria buscado anunciar que nas regras lingüísticas - entendidas como válidas em si mesmas - são sancionadas relaçõ̃es determinadas de poder. Por esta razão, o tratamento dispensado por ele à linguagem parte dos limites desta, de sua impossibilidade de apreender as coisas em si mesmas, para desembocar na pergunta pela origem do impulso que visa ultrapassar estes limites. Às regras da linguagem não corresponde nada que estivesse para além das relações humanas, nada que existisse "em si mesmo". O ponto de partida contém, portanto, uma questão epistemológica - os limites do conhecimento edificado sobre a linguagem -, questão esta que reformulará o problema como problema moral - normas das relações humanas em um todo social. Pode-se dizer que ele parte dos limites da linguagem para refletir o "mundo", para abordá-la como instrumento apto a revelar as regras da comunicação e, através destas, as normas da convivência estabelecidas por valores que se impõem como inquestionáveis.

Na realidade, o "Curso de Retórica" apenas nos permite vislumbrar a direção na qual se orienta a crítica de Nietzsche como crítica à moral. Tal conformação da crítica à linguagem apenas será concretizada através da noção de Trieb zur Wahrheit, que ocupa um lugar central em Ueber Wahrheit und Luege im aussermoralischen Sinne. Aí, Nietzsche poderá dizer explicitamente que sua questão é uma questão moral. Conforme consta na parte final do texto inicialmente citado, o que está enfatizado neste texto, na medida em que é lido do ponto de vista da moral ("expresso moralmente"), é a obrigação de mentir em rebanho, em um "estilo obrigatório para todos" (grifos meus). "Trieb zur Wahrheit" servirá justamente para designar o impulso inconsciente que impele o membro da coletividade à busca das figuras retóricas fixadas. "Impulso" indica que ele o faz acreditando que estas são 
determinadas por referenciais externos às ações humanas, portanto, mostrando-se incapaz de reconhecer como tal uma exigência que está circunscrita ao plano dos valores. "Valores", neste texto, poderiam, portanto, ser entendidos como regras das relações entre os homens que, quando hipostasiadas, apresentam-se como leis determinantes das relações entre homem e "mundo", como conformidade entre leis da natureza e leis do conhecimento racional. A irracionalidade presente na fundamentação destas idéias seria o que Nietzsche pretende atestar e, ao fazê-lo, denunciar a determinação moral que as impede de superar o simples estágio da crença.

Tal impossibilidade de apreensão racional, pelo todo coletivo, do que seria originalmente sua "verdade" - a saber, a impossibilidade de a coletividade apreender a "verdade", por ela "espontaneamente" buscada (o "impulso à verdade") enquanto uma introjeção da norma social que coage à veracidade - indica que aquilo que parece ser uma preocupação da teoria do conhecimento se impõe, se visto mais detidamente, como determinado por um valor moral. A idéia de pureza, assim como a idéia de adequação é devedora de um valor estético "moralmente imposto", e não pode reivindicar estatuto epistemológico diferenciado da idéia de estilo.

Abstract: This paper intends to show that Nietzsche's criticism on language, already in his very first writings on these theme, cannot be taken in a merely epistemological sense, since discussion about knowledge is focused under a moral view.

Keywords: drive for truth - rethorics - morals - language 


\section{Notas}

(1) Tradução de Rubens R. Torres Filho. Usaremos essa tradução sempre que for possível. Caso contrário, será consultada a tradução da Gallimard da edição crítica de Colli e Montinari.

(2) Há divergências entre os comentadores quanto à datação deste escrito. $\mathrm{Na}$ edição Musarion, o texto é datado de 1874. P. Lacoue-Labarthe e J.-L. Nancy acreditam serem anotações de 1872. Cf. A. Meijers (Meijers 7, p. 384), há dois grandes argumentos em favor de 1874, a saber: 1 . o anúncio de um curso de retórica intitulado "Darstellung ueber Rhetorik" para o semestre de verão de $1874 ; 2$. somado a este, há um outro fato: Nietzsche escreveu a Gersdorff afirmando que daria um curso sobre retórica no semestre de verão de 1874. Labarthe e Nancy extraem a conviç̧ão de que o escrito data de 1872 de duas outras fontes: 1. a partir da cronologia estabelecida por K. Schlechta; 2 . de uma tabela de cursos das universidades alemãs publicada em um periódico de filologia. Em favor de 1872, me pareceu, no entanto, decisivo o argumento de Meijers, que, após documentar detalhadamente a compilação de trechos de G. Gerber efetuada por Nietzsche nesses apontamentos, observa que o livro de Gerber fora emprestado por Nietzsche junto à biblioteca de Basiléia no semestre de inverno de 1872/ 73 (Meijers e Stingelin 8, p. 380). A este dado pode ser somado o fato de que a comparação das anotações deste "Curso de Retórica" com Ueber Wahrheit und Luege im aussermoralischen Sinne parece indicar, como será buscado demonstrar nas páginas que se seguem, que o primeiro destes escritos constitui uma espécie de preparação para o segundo, o qual é datado de 1873, segundo Colli e Montinari. Diante disso, Meijers entende que as anotações para o curso, se é que realmente Nietzsche o tenha ministrado, foram feitas anteriormente à data para a qual ele estava previsto.

(3) Foram utilizados para este trabalho os trechos editados pela Musarion.

(4) Esta ampliação do universo por ele criticado irá situar seu tratamento da linguagem no domínio de uma crítica à moral, o que aqui será apenas apontado, conforme dito mais acima. 
Fonseca, T.L., discurso (25), 1995: 97-119

(5) Trata-se, aqui, da definição presente na Retórica de Aristóteles. Há também referências explícitas ao Organon $e$ indícios de menções à Poética. Por essa razão, a abordagem da discussão de Nietzsche com Aristóteles a ser feita aqui se limitará a essas obras, o que implica abdicar da pretensão de questionar a legitimidade da compreensão nietzschiana do tratamento que Aristóteles dispensa à linguagem, coisa que exigiria uma análise de outras obras sobre o tema.

(6) A tradução de dúnamis por "força" segue a tradução de Nietzsche ("Kraft") tal como consta no seu comentário sobre o trecho feito logo a seguir.

(7) Em verdade, o texto de Nietzsche contém quatro pontos. Aqui, porém, iremos tratar dois deles (o primeiro e o último) conjuntamente, já que, no que diz respeito àquilo que buscaremos enfatizar da compreensão nietzschiana deste texto de Aristóteles, seria repetitivo abordar cada um desses pontos separadamente.

(8) Seg. tradução de Dufour: “(...) é manifesto que a retórica serve igualmente para descobrir o persuasivo verdadeiro e o persuasivo aparente, assim como a dialética o silogismo verdadeiro e o silogismo aparente; pois, o que faz a sofística não é a faculdade, mas a intenção; existe, entretanto, uma diferença: aqui se é orador, este, por sua ciência, aquele por sua intenção; se é sofista em razão de sua intenção e dialético em razão não de sua intenção, mas de sua faculdade". Obs.: onde este tradutor usa "faculdade" leia-se "dúnamis" (Aristóteles 3, p. 75).

(9) O primeiro ponto enfatizado por Nietzsche pode ser assim reconstituído: a retórica não é uma epistemé, nem uma tekhné, mas é uma dúnamis no sentido em que é algo que tem seu aperfeiçoamento dado pela ação para que se torne uma tekhné.

(10) Observa-se que, a não ser pelo fato de que Nietzsche efetua uma análise termo a termo da definição aristotélica, este último item poderia ser tratado juntamente com o primeiro, já que ambos estão estreitamente relacionados. Esta relação se revela quando se observa que a retórica, para Aristóteles, para passar de dúnamis para tekhné exige uma preparação teórica.

(11) "Segundo os sicilianos Córax e Tísias, a retórica é dona da persuasão(retoriké esti peithoûs demiourgós)" (Nietzsche 10, p. 289). Obs.: a tradução é de LacoueLabarthe. 
(12) Quanto a esse ponto, Nietzsche menciona Quintiliano: "(...) as metáforas não artísticas - in quo propium deest - eram imputadas (como Quintiliano) aos indoctis ac non sentientibus" (Nietzsche 10, p. 315).

(i3) Vê-se que Nietzsche parte da suposição de que há não apenas em Aristóteles, mas, também, em diversos autores antigos, uma concepção dualista da lingua$\mathrm{gcm}$, a qual entende que ela possa ser artificial (thesei) ou natural (physei). Deste ponto de vista, a retórica seria fruto de um processo corruptor da linguagem naturalmente instaurada, daí ser um "artificio". Através dessa compreensão, Nietzsche chega a alinhar a concepção aristotélica da linguagem ao Crátilo no que diz respeito à alternativa dualista para o surgimento da linguagem aí formulada por Platão. Tal aproximação provavelmente encontraria diversos obstáculos se Nietzsche houvesse considerado também De Interpretatione. Como bem mostra P. Aubenque, não se pode afirmar a presença da concepção de "linguagem natural" nesta obra de Aristóteles (ver Aubenque 4, pp. 94-162).

(14) Em se atentando para os textos posteriores a esse período, vê-se que a menção a esta figura é recorrente quando Nietzsche busca angariar argumentos contra a exatidão dos nomes. O exemplo citado mais adiante - Schlange = enrodilhar-se - é reconstituído em Ueber Wahrheit und Luege im aussermoralischen Sinne.

(15) Sarah Kofman (ver Kofman 5, pp. 41-85) enfatiza o caráter originalmente metafórico que teria toda linguagem para Nietzsche. De fato, a metáfora ganha progressivamente maior importância do que as outras figuras nas obras subseqüientes. Entretanto, no trecho mencionado Nietzsche atribui explicitamente à sinédoque a criação dos nomes.

(16) A metonímia se mostrará cada vez mais importante no decorrer do desenvolvimento da discussão sobre a linguagem em Nietzsche, inclusive no periodo maduro (a partir de 1883), pois em tal figura residirá a raiz dos procedimentos antropomórficos que resultarão na criação de uma idéia de "substância" própria da "coisa" a partir do efeito que é produzido subjetivamente.

(17) Contrariamente a essa crítica de Nietzsche, poder-se-ia dizer que a comunicação por palavras poderia unicamente pretender transmitir impressões subjetivas e que suas exatidão e eficiência não teriam que prestar contas às "coisas em si mesmas". Tal argumentação se daria no sentido de mostrar que mesmo sendo 
trópica, a linguagem poderia ser exata quando usada para transmitir algo como "estados d'alma". Diante disso, Nietzsche terá ainda de mostrar que, mesmo quando se pretende que a linguagem apenas deva comunicar impressões subjetivas, ainda se está atribuindo uma tarefa excessiva à linguagem. Conforme será visto logo a seguir, a comunicação através da palavra somente pode suscitar emoções no interlocutor.

(18) Aqui começa a se delinear a apropriação de G. Gerber por Nietzsche de maneira evidente. Cf. o esquema apresentado por Meijers do trecho correspondente de Die Sprache als Kunst, Gerber concebe a formação da palavra da seguinte maneira: "(Ding an sich) - Nervenreiz - Empfindung - Laut - Vorstellung - Wurzel - Wort - Begriff" não havendo necessidade alguma na transição entre as diferentes etapas do processo (Meijers e Stingelin 8, p. 377). Ao contrário, cada uma destas constitui-se de algo qualitativamente distinto das demais, não podendo preservar nada da anterior e tampouco transmitir nada para a etapa posterior.

(19) Por meio desse segundo argumento, pode-se deduzir: mesmo que meu ouvinte ou interlocutor tenha razões indubitáveis para crer em minha honestidade, isto é, mesmo que sua confiança não seja proveniente de meu discurso, mas sim resultante de outras fontes, sua discordância ou sua concordância em relação à causa que eu defendo pode provir de uma incontornável imprecisão da linguagem. Desta forma, poder-se-ia entender que Nietzsche estaria aqui aludindo à terceira $e$ última prova técnica do discurso retórico segundo Aristóteles, a saber, aquela que se apóia sobre o "valor demonstrativo do discurso": “(...) quando fazemos extrair o verdadeiro e o verossímil daquilo que cada assunto comporta de persuasivo" (Aristóteles 3, p. 77).

(20) Com este primeiro argumento, pode-se suspeitar que, embora Nietzsche não o afirme, são visadas aqui as duas primeiras "provas técnicas" características do discurso retórico segundo Aristóteles (ver Aristóteles 3, pp. 76-77). A primeira delas diz respeito ao caráter do orador, ou seja, trata-se da habilidade deste de inspirar confiança através de seu discurso, o que significa manejar o discurso de forma que o ouvinte creia que este orador tem a intenção de transmitir aquilo que ele efetivamente está experimentando enquanto estado interno. A segunda prova refere-se às paixões do ouvinte, através do que a persuasão ocorre quando o discurso o leva a experimentar uma paixão determinada segundo a intenção do orador. 
(21) Nesta etapa da discussão, abre-se um flanco que permitiria um confronto entre a crítica de Nietzsche à linguagem e a concepção aristotélica da mesma em De Interpretatione, já que nesta obra a linguagem é abordada como meio de comunicação de estados d' alma.

(22) A multiplicidade de sentidos possíveis para a palavra "umschreiben" impede que se encontre uma boa tradução na língua portuguesa, pois, além de "circunscrever", ela pode significar "transcrever", "refundir", "parafrasear" e, em sentido figurado, "dizer por perífrase". Como se vê, esses diversos sentidos não apenas são cabíveis no contexto, como ainda podem enriquecer a interpretação do trecho em questão, quando se tem em vista a idéia de uma linguagem como originalmente retórica.

(23) Em Vom Ursprung der Sprache, a explicação para a origem da linguagem, tema central deste escrito, é outra. Aí, a linguagem não aparece como criação individual, mas como produto de um instinto (Instinkt) que se expressa "na massa e no indivíduo", podendo, portanto, ser criada por uma coletividade (ver Nietzsche 12 , parte I). Tal autoria coletiva está totalmente excluída neste "Curso de Retórica".

(24) Esta questão se relaciona ao problema de explicar de que forma a linguagem, já que essencialmente retórica, alcança uma forma única e serve para a comunicação. Isto significa, também, explicar de que maneira se dá a passagem da criação individual para o uso coletivo.

\section{Referências Bibliográficas}

1. ANDLER, C. Nietzsche, sa Vie et sa Pensée, Vol. I. Paris, Gallimard, 1958.

2. ARISTÓTELES. De Interprétation. In: Organon, Vol. I. Tradução de J. Tricot. Paris, Vrin, 1969. 
3. Rhétorique, Vol. I. Tradução de J. Dufour. Paris, Les Belles Lettres, 1932.

4. AUBEnQUE, P. Le Problème de L'Être chez Aristote. Paris, Presses Universitaires de France, 1962.

5. KOFMAN, S. Nietzsche et la Métaphore. Paris, Galilée, 1988.

6. LACOUE-LABARTE, P. “Le Detour”. In: Poétique, nº 5. Paris, 1975.

7. MEIJERS, A. "Gustav Gerber und Friedrich Nietzsche". In: Nietzsche Studien, $\mathrm{n}^{2}$ 17. Berlim, Walter de Gruyter, 1988.

8. MEIJERS, A. e STINGELIN, M. "Konkordanz - G. Gerber und F. Nietzsche”. In: Nietzsche Studien, n 17. Berlim, Walter de Gruyter, 1988.

9. NIETZSCHE, F. Der Letzte Philosoph. In: Vorarbeiten zu einer Schrift ueber den Philosophen (1872/73 - 1872). Gesammelte Werke, Vol. 6. Munique, Musarion, 1922.

10. Rhetorik. Gesammelte Werke, Vol. 5. Munique, Musarion, 1922.

11. Ueber Wahrheit und Luege im aussermoralischen Sinne. Saemtliche Werke. Colli e Montinari (orgs.), vol. 1. Berlim, Walter de Gruyter, 1980.

12. Vom Ursprung der Sprache. In: Einzelne Gedanke aus den Jahren 1869-1875. Gesammelte Werke, Vol. 5. Munique, Musarion, 1922.

13. PLATÃO. Cratyle. Tradução de Émile Chambry. Paris, Flammarion, 1967. 